\title{
Doğal Renkli Pamuk: Genel Özellikleri ve Tekstil Alanında Yapılan Önceki Çalışmalar
}

\author{
Muhammed Fatih YÜKSEL ${ }^{1 *}$, Gürkan ŞENEL ${ }^{1}$, Rıza ATAV ${ }^{2}$ \\ ${ }^{1}$ Eren Perakende Satış ve Mağazacılık A.Ş. , Ar-Ge Merkezi, Tekirdağ, Türkiye \\ ${ }^{2}$ Tekstil Mühendisliği Bölümü, Çorlu Mühendislik Fakültesi, Namık Kemal Üniversitesi, Tekirdağ, Türkiye \\ ${ }^{* 1}$ fatih.yuksel@erenperakende.com ${ }^{1}$ gurkan.senel@erenperakende.com ${ }^{2}$ ratav@nku.edu.tr
}

\begin{abstract}
Öz: Tekstil endüstrisinin vazgeçilmez hammaddelerinden biri olan pamuk, beyaz rengin ötesinde çeșitli kahve ve yeșil tonlarında da üretilebilen doğal bir elyaftır. Doğal renkli pamuk, sahip olduğu çeşitli özelliklerle tekstil endüstrisi için yenilikçi katma değeri yüksek ürünler geliştirilmesinde önemli bir firsat sunmaktadır. Çevredostu üretimin büyük önem kazandığ günümüz koşullarında atık yükü oluşturmayan yeni proseslerin ve üretim yöntemlerinin geliştirilmesi büyük önem kazanmıştır. Terbiye prosesleri arasında en fazla atık yükü oluşturan boyama işlemlerini ortadan kaldırmanın ve böylece önemli çevresel avantajlar elde etmenin bir yolu doğal lifin renkli olarak yetiştirilmesidir. Renkli pamuk üretimi her ne kadar uzun yıllar önce başarılmış bir konu olsa da literatür incelendiğinde renkli pamukların fiziksel-teknolojik özellikler açısından beyaz pamuğa göre geride kalıyor olmasının bu liflerin yaygın kullanımı üzerinde önemli bir engel teşkil ettiği anlaşılmaktadır. Bu çalışmada, renkli pamuğun yetiştiriciliği ve türleri hakkında özet bilgi verildikten sonra; liflerin genel özellikleri, avantaj ve dezavantajları ile renkli pamuk konusunda bugüne kadar yapılmış tekstil alanındaki önceki çalışmalara ilişkin literatür özeti sunulmaktadır.
\end{abstract}

Anahtar kelimeler: Doğal renkli pamuk, boyama, çevredostu

\section{Natural Colored Cotton: General Properties and Previous Studies in Textile Field}

\begin{abstract}
Cotton, one of the indispensable raw materials of the textile industry, is a natural fiber that can be produced in various shades of brown and green beyond the white color. Naturally colored cotton offers an important opportunity to develop innovative products with high added value for the textile industry with its various properties. In today's conditions, where environmentally friendly production is of great importance, the development of new processes and production methods that do not create waste has gained great importance. One way to eliminate dyeing process that creates the largest waste load among finishing processes and thus gain significant environmental advantages is to grow colored natural fiber. Although the production of colored cotton is a subject that has been accomplished many years ago, when the literature is examined, it is understood that the fact that colored cotton is behind white cotton in terms of physical-technological properties poses a significant obstacle to the widespread use of these fibers. In this study, after giving brief information about the cultivation and types of colored cotton; a literature survey on the general fiber characteristics, advantages and disadvantages of colored cotton and previous studies in textile field on colored cotton is presented.
\end{abstract}

Key words: Naturally colored cotton, dyeing, environmentally friendly

\section{Giriş}

Tekstil endüstrisinde hammadde olarak birçok farklı türde lif kullanmaktadır. Bu liflerin bazıları, medeniyetin ilk yıllarından günümüz modern zamanlarına kadar uzanan bir sürede kullanılagelmiştir. Temel olarak yeni bir elyaf türünün piyasaya sürülmesinin maliyetli olacağı kanısı nedeniyle ancak elyafın performans veya başka bir açıdan diğer liflerden ayrılan özelliği varsa o elyaf pazara tanıtılabilmektedir. Liflerin gelişimini etkileyen faktörlerden bazıları eğrilebilme kabiliyetleri, yeterli miktarda bulunabilirlikleri, üretim maliyeti ve sahip olduğu özelliklerinin tüketiciler tarafindan istenirliliği olarak sayılabilir [1].

Pamuk (Gossypium hirsutum L.) elyafi, tekstil endüstrisi için en önemli hammaddelerden biridir ve dünyanın tekstil ticaretinin belkemiğidir [2]. Dünyada az sayıda ülke ekolojisinin pamuk tarımına elverişli olması nedeniyle, dünya üretimi Türkiye'nin de içinde bulunduğu az sayıda ülke tarafından gerçekleştirilmektedir. Uluslararası Pamuk İstişare Komitesi (ICAC)'nin 2014-2018 arası 5 yıllık döneme ilişkin verileri incelendiğinde dünyada ortalama 32,1 milyon hektar alanda pamuk ekimi yapıldığı ve bu ekimden ortalama 24,6 milyon ton pamuk lifi elde edildiği görülmektedir. Dünya pamuk lifi veriminin en yüksek olduğu ülke Avustralya'dır. 2018/19 sezonunda ICAC verilerine göre Türkiye ise $1944 \mathrm{~kg} /$ ha'lık üretimle pamuk veriminde ikinci sıraya yükselmiştir.

\footnotetext{
* Sorumlu yazar: fatih.yuksel@erenperakende.com Yazarların ORCID Numarası: ${ }^{1 *} 0000-0003-4239-3212,{ }^{1} 0000-0003-4320-1729^{2}$ 0000$0002-5807-4542$
} 
Dünyada en çok pamuk tüketen ülkeler yine en çok üretim yapan ülkelerdir. Dünya pamuk tüketiminden en büyük payı 8,4 milyon ton ile Çin almaktadır [3].

Tekstil endüstrisinin en yaygın hammaddesi pamuk, alışılmış beyaz renginin dişında da renklere sahip olabilmektedir [4]. Doğal renkli pamuk doğada bulunan renkli pamuk tohumlarından ve ayrıca bunların genetik olarak değiştirilmesiyle üretilen tohumlardan elde edilmektedir. Doğal halde beyaz, yeşil, kahverengi ve bu renklerin tonlarında bulunmakla beraber diğer renklerin elde edilebilmesi için yapılan çalışmalar dünya genelinde ve ülkemizde devam etmektedir [5]. Renkli liflere sahip pamuk bitkileri çok uzun bir süredir yetiştirilmektedir [2], ancak iki nedenden dolayı gelişmeleri beyaz elyaf pamuğundan daha yavaş olmuştur. İlk olarak, renkli elyaf pamuğun verimi beyaz elyaf pamuğunkinden çok daha düşüktür [6]. İkincisi ise, tekstil endüstrisinde kullanılan ucuz boyarmadde türleri mevcuttur ve bu tür uygulamaların olumsuz sonuçları uzun süredir göz ardı edilmiştir [7]. Bunun sonucunda tekstil endüstrisi her rengi elde edebilmek için beyaz pamuğu tercih etmiştir [8]. Ticari olarak pazarlarda ulaşılabilen renkli pamuk Amerika'nın yerli nüfusu tarafından yüzyıllardır üretilmekte ve tarımı yapılmaktadır [9]. Dünyadaki en çok renkli pamuk üreten diğer ülkeler ise Çin, Hindistan, Pakistan ve Özbekistan'dır [10].

Son zamanlarda çevreye ve insana dostça yaklaşan üretim stratejileri ve endüstriyel işlemlerin gündeme gelmesi nedeniyle, doğal renk pigmentlerini içeren ve de organik olarak yetiştirilecek "renkli pamuk üretimi" konusuna dikkatler çevrilmiştir [9]. Doğal renkte pamuklar, beyaz dışındaki doğal renklere sahip lifleri ifade etmektedir [11]. Organik ve doğal renkli pamuk liflerinin, kumaş ve giysi üretimi ile ilgili bazı firmalar ve üreticiler tarafindan el sanatları, örgü, gömlek, süveter, çorap, havlu, iç çamaşırı ve diğer giyim eşyaları, ev dekorasyonları ve mefruşat alanlarında kullanılabilirlikleri gösterilmiştir ve böylelikle de bu ürünlerin ABD, Avrupa ve Japon pazarlarına tanıtımları başlamıștır [9].

Doğal renkli pamuk, gelecekte farklı ürünler geliştirilmesi için araştırılabilecek kirlilik içermeyen, çevre dostu, enerji tasarruflu, uygun maliyetli, toksik olmayan, yeni uygulanabilir bir tekstil hammaddesidir. Dünya kirlilik içermeyen organik tekstil ve ürünlere doğru yönelirken, doğal renkli pamuk pazardaki anahtar kelime haline gelecektir. Bunun nedeni ise; doğal renkli pamuk üretim sürecinin, tekstil ürünleri imalatının en kirletici faaliyetini (boyama) ortadan kaldırmasıdır [12]. Küresel tekstil faaliyetlerinin olumsuz çevresel etkileri olan kimyasal atık akışı göz önünde bulundurulursa doğal renkli pamuğun bu faydası sayesinde büyük bir başarıya sahip olacağı düşünülmektedir [11]. Ev tekstili, gündelik giyim, döşemelik kumaşlar ve sentetik boyalı tekstil malzemelerinin olası her ikamesinde geliștirilip uygulanabilirler. Renkli pamuk hem benzersiz hem de arzu edilen özelliklere sahip olan tüketiciye ve çevreye fayda sağlayan bir tekstil hammaddesidir [12]. Doğal renkli pamuklardan üretilen kumaşlar ve giysiler çevreye daha küçük ayak izleri bırakır ve bu nedenle doğal renkli pamuklara genellikle "çevre dostu pamuk" denir [11].

\section{Doğal Renkli Pamuk Yetiştiriciliği}

Renkli pamuğun dikim ve yetiştirme yöntemi beyaz pamuğunkine benzer. Akılda tutulması gereken en önemli şey, renkli pamukların dikim esnasındaki izolasyonudur. Bu izolasyon, beyaz pamuğun ve farklı renklere sahip diğer renk pamukların izolasyonunu içermektedir. Çapraz kirlenmeyi engellemek adına dikim izolasyon planı oldukça önemlidir. İzolasyon, bir örtme ağının kullanılması veya mesafeli dikim gibi fiziksel izolasyon yolları ile elde edilebilir. Birinci yöntem sadece küçük deneysel çalışmalar için uygundur. İkincisi ise ticari üretimde kullanılmaktadır [11].

Beyaz pamuğa kıyasla, renkli pamuk kullanmanın avantajı, düşük karbon ayak izinden kaynaklanmaktadır. $\mathrm{Bu}$, renkli pamuk lifleri üretilirken ve kullanılırken herhangi bir kirlilik formunun da minimumda tutulacak olması anlamına gelmektedir. Öncelikle süreç böcekler, yabani otlar ve hastalıklar da dâhil olmak üzere zararlılara karşı yerleşik bir direnç gösteren ekim çeşitliliği ile başlar. Daha sonra bütüncül bir haşere yönetimi sisteminin uygulanabileceği iyi bir büyüme ortamı geliştirmek ve bu ortamı sürdürmek ile devam ettirilir. Haşere kontrol uygulamalarında önce doğal ve biyolojik esaslar göz önünde bulundurulmalıdır. Pestisit uygulama oranları, insanlar ve hayvanlar için belirtilen minimum miktarda ve düşük toksisitede olmalıdır. Gübreleme için mümkün olduğunca organik gübreler tercih edilmelidir. En son aşamada ise yetiştirme koşulları optimize edilmelidir. Örneğin, alana farklı bir mahsul ekilmesi, yabancı otların kontrol altına alınmasında yardımcı olabilir. Uygulamaların, yerel koşullara göre optimize edilmesi gerektiği unutulmamalıdır [11].

Pamuk lifinin renkleri esas olarak genetik olarak belirlenmesine rağmen, güneş 1şığı ve toprak türleri gibi çevre faktörleri de lif rengini, özellikle renk yoğunluğunu etkilemektedir. Aynı türde olup ancak farklı ortamlarda yetişen liflerin farklı renk yoğunluklarına sahip olması çok yaygın bir durumdur. Aynı alandaki bitkiler arasında ve bazen aynı bitkinin kozaları arasında lif renk ayrımı gözlemlemek olağandışı değildir. Genel olarak, açık renk liflerin kalitesi beyaz liflerle kıyaslanabilirken, koyu renk liflerin kalitesi düşüktür. Kükürt içeren atmosfer veya 
asit yağmuru lif renk gelişimini büyük ölçüde etkiler. Yüksek kükürtlü bir ortamda yetişen yeşil pamuk çeşidinden kahverengi lifler üretilebilir. Bu nedenle, elyaf geliştirme aşamasında kükürt içeren bir gübre veya böcek ilacı uygulaması sınırlandırılmalıdır. Hasat mevsimi boyunca yüksek nem oluşursa lif rengi değişebilir. Uygun olmayan bir saklama durumu da elyaf rengini değiştirebilir [11].

Yukarıda belirtildiği gibi, güneş 1şığı etkisi pamuk liflerinin veya kumaşların doğal renklerini büyük ölçüde değişstirir. Yeşil renk kapalı ortam ışık koşullarında yavaş yavaş sarımsı yeşile, sonra da sarımsı kahverengiye dönüşecektir. Kahverengi pamukta, genellikle güneş 1şığına maruz kalan ve güneş 1şığına maruz kalmayan lifler arasında renk farkı görülmektedir. Güneş ışığına maruz kalan açık kahverengi, diğeri ise kırmızımsı kahverengi olmaktadir [11].

\section{Doğal Renkli Pamuk Türleri}

Doğal renkli pamuk, lümenin bir parçası olarak renkli pigment içeren liflerdir [12]. Şu anda doğal renkli pamuklar kahverengi ve yeşil olmak üzere iki büyük gruba ayrılmıştır. Her grup kendi altında, renk farkına göre alt gruplara ayrılabilmektedir. Örneğin, kahverengi pamuklar için, açık kahverengi, kırmızımsı kahverengi, koyu kahverengi, vb. vardır (Şekil 1). Doğal renkli pamuklar, en yüksek varyasyon konvansiyonel pamuk $G$. hirsutum'da, ikincisi G. arboreum'da ve daha az olarak G. barbadense ve G. herbaceum'da bulunmak üzere yetiştirilen her dört Gossypium türünde de bulunmaktadır. Doğal renkli pamuklar Çin ve Hindistan başta olmak üzere 27 ülkede yetiştirilmektedir [11].

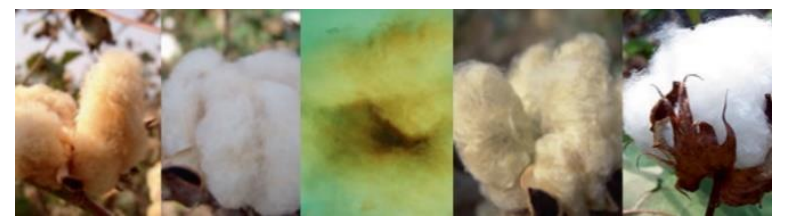

Şekil 1. Koyu kahverengi, açık kahverengi, koyu yeşil, açık yeşil, beyaz pamuk [11]

Doğal renkli pamukta bulunan pigmentler genellikle stabil değildir. Özellikle lif gelişimi döneminde (çiçek açılmasından koza olgunlaşmasına kadar) hava koşullarına bağlı olarak çevresel faktörlerden büyük ölçüde etkilenirler [11].

Renkli pamuklar arasında kahverengi en yaygın renktir. Kahverengi renk açık kahverengiden, yoğun maun kırmızısına kadar değişen farklı tonlarda bulunmaktadır. Rengin yoğunluğuna bağlı olarak, açık kahverengi, hâkî/devetüyü rengi, kahverengi, koyu kahverengi / çikolata rengi, kirli gri, ten rengi ve kırmızı-kahverengi renkler mevcuttur. Kahverengi renk yeşil renge kıyasla daha stabildir. Sürekli güneş ışığına maruz kaldığında, kahverengi renk de solar, ancak bu solma yeşil renge kıyasla çok daha düşük hızla gerçekleşir [12].

Yeşil, pamukta yaygın olarak görülen ikinci önemli renktir. Yeşil renk kahverengiden daha az yaygındır ve esas olarak açık yeşil ve yeşil olmak üzere iki tonda ortaya çıkar. Yeşil renk solmaya daha meyilli olduğundan kahverengi renkten daha hızlı solmaktadır. Koza açılması sırasında güneş ışığına uzun süre maruz kalınması yeşilin hızla solmasına neden olur ve renk beyaz, kirli beyaz veya kahverengimsi olur. Yeşil renk çoğunlukla $G$. hirsutum 'da gözlemlenir ve muhtemelen yeşil renk veren türler halen ticari tarım için serbest bırakılmamıştır [12].

\section{Doğal Renkli Pamuğun Özellikleri}

Renkli ve beyaz liflerin fiziksel ve kimyasal özelliklerinde farklılıklar vardır. Renkli lifler genellikle daha fazla miktarda vaks içerir, bu nedenle beyaz liflerden daha düşük emiciliğe sahiptir. Beyaz, kahverengi ve yeşil liflerin nem tutma özellikleri sırasıyla \%8,5, \%7,6 ve \%5,1'dir [11]. Doğal renkli pamuğun nem emiciliğinin düşük olmasının sebebinin daha yüksek hidrofobik bileşenler olduğu ileri sürülmektedir. Geleneksel beyaz pamukla kıyaslandığında yeşil renkli pamukta yağ, lignin ve pektin çok daha yüksektir [13].

Beyaz pamuk lifleri içerisinde organik çözücü ile ekstrakte edilebilir madde miktarı $\% 0,6$ oranında iken yeşil pamuk liflerinde bu oran \%14 ila 17 civarındadır. Bu nedenle yeşil pamuk lifleri beyaz liflerden daha pürüzsüz bir dokuya sahiptir [14].

Renkli pamuk lifi kalitesi son yirmi otuz yıldır önemli ölçüde iyileşmiş olsa da sürekli gelişen tekstil eğirme teknolojilerinin taleplerini karşılamak için daha iyi bir kaliteye sahip olması gerekmektedir. Beyaz pamukla karşılaştırıldığında doğal renkli pamuk genotiplerinin lifleri çok düşük kalitelidir. Doğal renkli pamuk lifleri beyaz pamuk liflerine göre daha kısa, daha dayanıksız ve daha az olgunlaşmıştır. Kahverengi pamuk liflerinin, üst yarı ortalama uzunlukları $22 \mathrm{~mm}$ 'den az olup mukavemeti yaklaşı $15 \mathrm{cN} /$ tex civarındadır. Koyu kahverengi pamuğun 
hem lif kalitesinin hem de veriminin kahverengi veya açık kahverengi bir pamuktan daha kötü olmasının nedeni genellikle çok geç olgunlaşmasıdır. Yeşil pamuklar için ise elyaf üst yarı ortalama uzunluğu yaklaşık $25 \mathrm{~mm}$, mukavemeti 11-18 cN/tex ve yaklaşık inceliği ise 2-2,5 mikroner indekstir [11]. Bu nedenle, özellikle yüksek hızda eğirme için uygun lif mukavemetini sağlamak üzere renkli pamuğun lif özelliklerini iyileştirmeye ihtiyaç vardır. Renkli G. hirsutum lif uzunluğu, mukavemeti ve renk haslığı gibi özellikleri açısından daha iyi sonuçlar elde etmek için beyaz renkli olanla çaprazlanmaktadır [12]. Renkli lifler sıklıkla beyaz liflerle ve bazen de sentetik liflerle karıştırılır. Renkli liflerin ve beyaz liflerin harmanlama oranlarının ayarlanmasıyla çok çeşitli renkler elde edilebilir [11].

Doğal pigmentli yeşil pamuk, rengini lifin dış tarafinda selüloz katmanlarında bulunan suberin (balmumu) tabakasındaki sinamik asit türevi olan kafeik asitten almaktadır $[15,16]$. Bu, floresan bir bileşiktir ve amacının tohumu korumak için UV radyasyonunu absorblama olduğu düşünülmektedir. Bu sonuç, doğal pigmentli yeşil pamuğun geleneksel ağartılmış pamuğa kıyasla üstün UV koruyucu özelliğe sahip olabileceği tartışmalarına yol açmıştır [17]. Kahverengi ve taba rengi pamuklar renklerini, yeşil pamuğun rengini aldığı suberin tabakası yerine lif hücrelerinin lümenindeki tanen hücrelerinden almaktadır [18]. İnce tabaka kromatografi analizi (TLC) ile renk pigmentinin tanen türevleri olduğu ortaya koyulmuştur. Kahverengi renk, lifler oksijene ve güneş 1şığına maruz kalana kadar oluşmaz, tohum kabuğu açıldığında renk meydana gelir. Bir diğer ilgi çekici nokta ise doğal pigmentli pamukların UV koruyucu özelliklerinin stabilitesinin uzun süreli olmasıdır [17].

Doğal renkli pamuğun diğer özellikleri arasında, geleneksel beyaz pamuğa göre daha fazla ağır metal içermesi nedeniyle aleve dayanıklılığının daha fazla olması ve daha yüksek sınırlı oksijen indeksi değerine sahip olmasıdır [19].

Bilindiği gibi bir lifin tekstil açısından en önemli özellikleri higroskopik nem içeriği, yabancı madde içeriği, inceliği, mukavemeti ve uzunluğudur. Tablo 1'de beyaz ve renkli pamuk liflerinin söz konusu özellikleri karşılaştırılmaktadır.

Tablo 1. Beyaz ve renkli pamuk liflerinin çeşitli lif özelliklerinin karşılaştırılması [7, 11, 14, 19]

\begin{tabular}{ll}
\hline \multicolumn{1}{c}{ Lif özelliği } & \multicolumn{1}{c}{ Karşılaştırma } \\
\hline Su emiciliği & Beyaz Pamuk > Renkli Pamuk \\
\hline Higroskopik nem içeriği & Beyaz Pamuk > Renkli Pamuk \\
\hline Organik çözücü ile ekstrakte edilebilir madde miktarı & Beyaz Pamuk < Renkli Pamuk \\
\hline Lif inceliği (Mikroner indeks) & Beyaz Pamuk > Renkli Pamuk \\
\hline Lif mukavemeti (cN/tex) & Beyaz Pamuk > Renkli Pamuk \\
\hline Stapel uzunluğu (mm) & Beyaz Pamuk > Renkli Pamuk \\
\hline Yanıcılığı & Beyaz Pamuk > Renkli Pamuk \\
\hline
\end{tabular}

Tablo 1'den görülebileceği üzere renkli pamuk lifleri bütün özellikleri açısından beyaz pamuk liflerine kıyasla dezavantajlıdır.

Beyaz pamuk çeşitlerine göre doğal renkli pamukların çeşitli avantajları vardır. Bunlar aşağıda kısaca açıklanmaktadır.

İnsan Să̆lı̆̆ına Etkisi: Sentetik boyarmadde içeren pamuklu kumaşların cilt ve insan sağlığı üzerinde olumsuz etkileri olduğu bilinmektedir. Sentetik boyarmaddeler ciltte alerjiye ve kaşıntıya neden olabileceği gibi bazen cilt kanserine dahi neden olabilir. Doğal renkli pamuk liflerinden mamul edilen kumaşlarda bu tür olumsuz etkiler ortadan kaldırılmaktadır. Bu kumaş, hassas cilde sahip olan kişiler tarafından bile güvenle kullanılabilir [12].

Cevreye Etkisi: Doğal renkli pamuklar, kimyasal boyaların kullanılmamasının yanı sıra pestisitlerin kullanımının azaltılması sayesinde ekoloji ve çevre açısından güvenli olmaları nedeniyle popüler hale gelmiştir. Ticari beyaz pamuk ise dünyada pestisite en çok ihtiyaç duyan mahsuldür. Dünyadaki tarım arazilerinin sadece \%3'ünü işgal etmesine rağmen, böcek ilaçlarının \%25'inden fazlasını ve dünya çapında kullanılan pestisitlerin \%12'sini tüketmektedir. Dünya Bankası, endüstriyel su kirliliğinin yaklaşık \%20'sinin tekstil boyama işleminden kaynaklandığını tahmin etmektedir. Ayrıca su kaynakları içerisinde sadece tekstil boyamasıyla ilgili 72 toksik kimyasal belirlemişlerdir. Doğal renkli pamuk kullanımı, sentetik boyarmaddelerin neden olduğu çevre kirliliğinin ve çiftçilerin ve toplumların sağlığı için oluşan risklerin azaltılmasına yardımcı olur [20].

Kumaş Üretim Maliyetine Etkisi: Doğal renkli pamuğun en önemli özelliklerinden birisi, boyama işleminin olmaması ve boyahanede bazı ön işlemlerin atlanmasıdır. Böylece kimyasal işlem sayıları sınırlandığında daha az su kullanımı, daha az atık su, kimyasalların daha az tüketimi, daha kısa işlem süreleri, daha az enerji kullanımı gibi sonuçlar olacaktır. Bunlar maliyet avantajı yanında, çevre korumaya da büyük katkıda bulunacaktır [8]. 
Yıkamanın Pamuk Rengi Üzerine Etkisi: Doğal renkli pamukların yıkanması sonucu elde edilen rengin konvansiyonel boyama ile elde edilen renklerin yıkanması sonucu elde edilene göre oldukça farklı olduğu söylenebilir. Doğal renkli pamuklu kumaşlar yıkama sonrası konvansiyonel boyama sonucu elde edilene göre her yıkamada haslığını ve renk yoğunluğunu geliştirir. Literatür ve yapılan araştırmalar, renkli pamuklu kumaşların yıkanmasının rengini yoğunlaştırdığını göstermiştir [21].

Öte yandan doğal renkli pamukların bazı dezavantajları vardır. Bunlar aşağıda kısaca açıklanmaktadır.

Düsük Verim Potansiveli: Hâlihazırda mevcut olan renkli pamuk genotiplerinin verim potansiyeli çok düşüktür. Verim potansiyeli, beyaz pamuk çeşitlerinin neredeyse yarısıdır. Düşük verim potansiyeli nedeniyle, doğal renkte pamuk ticari tarım için popüler değildir. Başka bir deyişle, doğal renkli pamuğun düşük verim potansiyeli yetiştiriciliğinin yaygınlaşmasında bir bariyer etkisi göstermektedir [12].

Kötü Lif Ö́zellikleri: Beyaz pamukla karşılaştırıldığında doğal renkli pamuk genotiplerinin lifleri daha düşük (stapel uzunluğu daha kısa, lif mukavemeti ve mikroner indeks daha düşük) kalitededir. Renkli pamuğun bu özellikleri özellikle ticari olarak eğirme için uygun değildir ve geliştirilmeye ihtiyacı vardır [7]. Genel olarak renkli pamuğun özelliklerinin beyaz pamuktan \%10 daha düşük olduğu ortaya koyulmuştur. Daha yüksek renk yoğunluğu eldesi odaklı genetik seçimin (seleksiyonun) lif üzerinde olumsuz etkiler oluşturduğu düşünülmektedir [22].

Sınırlı Renkler: Şu anda germplazmada bulunan doğal renkli pamuk genotipleri sınırlı renklere sahiptir. Kahverenginin çeşitli tonları ve yeşil olmak üzere sadece iki renk vardır. Sadece iki renkle, doğal renkli pamuğun beyaz pamukla rekabet etmesi düşünülemez [12].

Renklerin İstikrarsızlığı: Doğal renkli pamuğun rengi sabit ve uzun ömürlü değildir. Tüm renkler güneş 1şığında solma gösterebilmektedir. Güneş ışığında, yeşil renk kahverengi renkten daha hızlı solmaktadır. Kahverengi rengin solması ise oldukça yavaş bir hızda gerçekleşmektedir. Doğal renkli yeşil pamuğun güneş ışığına maruz kalan bölgesi neredeyse beyaz olur ve koza içinde kalan kısmı ise koyu yeşil kalır [7]. Renkli pamuk lifinin rengi üretimde ve uygulamada koyudan açığa doğru değişir ve renksizleşme ve rengin kirlenmesi problemleri ortaya çıkar [23].

Kontaminasyon: Doğal pamuk rengi, baskın / tamamlanmamış baskın genler tarafından yönetilir. Yeşil renk bir gen tarafindan kontrol edilirken kahverengi renk iki veya daha fazla gen ile kontrol edilmektedir. Pamuk genellikle çapraz tozlaşan bir üründür. Doğal koşullarda, çapraz tozlaşma \%5-20 oranında gerçekleşir. Yakınlarda renkli ve beyaz pamuğun yetiştirilmesi, beyaz pamuk genotiplerinin renkli genotiplerle, veya tersi, kontaminasyon ihtimalini artıracaktır. Bir önceki yıl renkli pamuğun yetiştirildiği alanda beyaz pamuğun yetiştirilmesi de kontaminasyona neden olabilir. Bu nedenle, renkli pamuk ekimi sadece küçük alanlarla sınırlandırılmalıdır [12].

Düsük Piyasa Talebi: Son yıllarda, doğal renkte pamuk talebi, bazı Avrupa ülkelerinde artmaktadır, bu da yılda yaklaşık 5-6 yüz bin balyadır. Düşük talebe bakıldığında, renkli pamukların yetiştirilmesinin sınırlı alanlarla ve sadece kayıtlı yetiştiricilerle sınırlandırılması uygun olacaktır. Bu, doğal renkli pamuk üreticilerinin, renkli pamuğun muhtemel aşırı üretimi ve çok az talep görmesi veya hiç talep görmemesi nedeniyle, yok olmasının önlenmesine yardımcı olacaktır [12].

Pazarlama Olanakları Eksikliği: Doğal renkli pamuk satışı için uygun pazarlama eksikliği vardır. Ticari ölçekte renkli pamuk yetiştiriciliğine başlamadan önce pazarlama imkânlarının geliştirilmesi gerekmektedir. Doğal renkte pamuk üretimi için alıcı ile üretici arasında yazılı bir anlaşma olmalıdır [12].

Tablo 2'de renkli pamuk liflerinin beyaz pamuğa kıyasla avantaj ve dezavantajları özetlenmektedir.

Tablo 2. Beyaz ve renkli pamuk liflerinin çeşitli lif özelliklerinin karşılaştırılması [7, 8, 12, 17, 20, 21]

\begin{tabular}{ll}
\hline \multicolumn{1}{c}{ Avantajları } & \multicolumn{1}{c}{ Dezavantajları } \\
\hline $\begin{array}{l}\text { Çevre kirliliğine olumsuz etkisi beyaz pamuğa } \\
\text { göre daha azdır. }\end{array}$ & Lifüretim verimi beyaz pamuk ile kıyaslandığında daha düşüktür. \\
\hline $\begin{array}{l}\text { Yıkama sonrası renk solması boyanmış beyaz } \\
\text { pamuğa kıyasla daha azdır. }\end{array}$ & $\begin{array}{l}\text { Işık ile renk solması boyanmış beyaz pamuğa kıyasla daha } \\
\text { fazladır. }\end{array}$ \\
\hline $\begin{array}{l}\text { UV koruma özelliği beyaz pamuğa göre daha } \\
\text { fazladır. }\end{array}$ & $\begin{array}{l}\text { Genel lif özellikleri (incelik, uzunluk, mukavemet vb.) beyaz } \\
\text { pamuğa kıyasla daha kötüdür. }\end{array}$ \\
\hline $\begin{array}{l}\text { Cilt ve insan sağlığı üzerinde olumsuz etkileri } \\
\text { boyanmış beyaz pamuğa kıyasla daha azdır. }\end{array}$ & $\begin{array}{l}\text { Beyaz pamukta boyama ile istenilen her renk elde edilebilirken } \\
\text { renkli pamuklar sınırlı renklerde mevcuttur. }\end{array}$ \\
\hline $\begin{array}{l}\text { Kumaş üretim maliyeti, gördüğü işlemlerin daha } \\
\text { az olması nedeniyle beyaz pamuğa kıyasla daha } \\
\text { düşüktür. }\end{array}$ & $\begin{array}{l}\text { Piyasada doğal renkli pamuğa olan talep daha olup renkli } \\
\text { pamuk satışı için uygun pazarlama eksikliği vardır. }\end{array}$ \\
\hline
\end{tabular}




\section{Doğal Renkli Pamuğun Tekstil Özellikleri Hakkında Yapılan Önceki Çalışmalar}

Literatürde Christidis ve Harrison'ın 1955 yllında yaptıkları bir çalışmaya ilişkin verilen özet bilgide, Christidis ve Harrison'ın pamukta renkliliğin istenen bir özellik olmadığını, kahverengi ve yeşil renk ile ilgili genlerin birim uzunluk başına ağırlık bakımından lif gelişimini engelleyebileceğini bildirdikleri ifade edilmiştir. $\mathrm{Bu}$ araştırmacılar, aynı zamanda genellikle renk ve lif uzunluğu arasında negatif bir korelasyon olduğunu vurgulayarak özellikle de yeşil liflerin düşük lif indekslerine ve yüksek mum içeriklerine sahip olduklarını belirtmişlerdir. Ayrıca, eski Sovyetler Birliği'nde beyaz lifli standart çeşitler kadar iyi kaliteli renkli pamukların seleksiyon ile geliştirildiğini de ifade etmişlerdir [24].

1982 yilında Sally Fox, Wickenburg ve Arizona'da doğal renkli pamuğun uzunluğunu ve mukavemetini geliştirmek için bir ıslah ve seleksiyon çalışmasına başlamıştır. 1988 yllında Sally Fox, makinede başarıyla eğrilebilecek uzunlukta doğal renkli pamuk hibritleri geliştirmiştir. Sally Fox, doğal renkli pamuk şirketini kurarak sslah ettiği pamuk çeşitlerini; FoxFibre ${ }^{\circledR}$, Fox markets, FoxFibre ${ }^{\circledR}$ Green, Coyote Brown, Buffalo Brown ve Palo Verde Green olarak tescil ettirmiştir [21].

Yatsu, Espelie ve Kolattukudy (1983) yaptıkları çalışmada elektron mikroskobu yardımı ile yeşil pamuk lifi içinde suberin varlığını araştırmışlardır. Yeşil pamuk (Gossypium hirsutum L.) liflerinin hücre lümeni çevresinde çok sayıda ince eş merkezli halkaya sahip olduğu tespit edilmiştir. Bu halkaların, suberine benzer karakteristikte ince bir yapıya sahip olduğu bulunmuştur. $\mathrm{LiAlD}_{4}$ depolimerizasyonu ve gaz kromatografisi-kütle spektrometrisi analizi ile bulunan başlıca alifatik monomerler olan hidroksikokosanoik asit (\%70) ve dokosanedoik asit (\%25), yeşil pamukta suberin polimerinin varlığını göstermiştir [14].

VanZandt, Horridge ve Dever (1997) tarafindan yapılan bir çalışmada binek araç ve uçak koltuğu döşemeleri için doğal renkli pamukların kabul edilebilirliklerini belirlemek amacıyla (302 Motorlu Taşıt Güvenliği Standardına göre) iki doğal renkli pamuktan elde edilen dimi konstrüksiyona sahip dokuma kumaşın alev direnci ve fiziksel özelliklerini araştırmışlardır. Çalışmada ayrıca pamuk tipi, alev geciktirici kimyasal konsantrasyonu ve kuru temizleme parametrelerinin kumaşların alev direnci ve fiziksel özellikleri üzerindeki etkisi değerlendirilmiştir. Çakal ve bufalo kahverengisi pamuk liflerinden yapılan dimi kumaşların, 302 Motorlu Taşıt Güvenliği Standardı gereksinimini karşılamak için gerekli olan yanma performansını $(4,4-4,5 \mathrm{~cm} / \mathrm{dk}$.) sağladığı tespit edilmiştir [25].

Dickerson, Lane ve Rodriguez (1999) tarafından yapılan bir çalışmada çeşitli yıkama kimyasallarının (optik deterjanlar, fosfat, klor ve klorsuz ağartıcılar) doğal renkli pamuk liflerinden üretilmiş kumaşların renk değişimi ve dayanıklılı̆̆ üzerindeki etkileri araştırılmıştır [7].

Richards, Rowe ve Stankovic Elesini (1999) tarafindan yapılan bir çalışmada, bazı Amerikan doğal renkli pamuk çeşitlerinin yapısal ve mekanik özellikleri nicel olarak değerlendirilmiştir. Liflerin sekonder çeperinin alternatif selüloz katmanlarından ve suberin adı verilen mumsu bir organik maddeden oluştuğunu ileri süren doğal renkli yeşil pamukların morfolojisi üzerine daha önce yapılan çalışmadan yola çıkan Richards, Rowe ve Stankovic, suberin yüzdesini belirlemek için, pamuk numunelerini etanol ile ekstrakte etmiştir. Lif şişmesinden elde edilen veriler, yeşil pamuk elyafının büyük oranda suberin içerdiğini göstermiştir. Doğal renkli liflerin, kabul edilebilir seviyede özelliklere sahip olmalarına rağmen, geleneksel beyaz liflerden daha düşük mukavemet ve kopma yüzdesine sahip olduğu tespit edilmiştir. Ayrıca renkli elyaf kristalinitesinin beyaz elyaftan daha düşük olduğu ancak yeşil renkli elyafın kahverengi ve beyaza nazaran daha da düşük olduğu saptanmıştır. Bunun nedenin ise sekonder çeperdeki alternatif suberin ve selüloz katmanlarını, kristalitlerin gelişimini inhibe etmesi olabileceği düşünülmüş, yeşil elyaf etanol ile tamamen ekstrakte edildiğinde kristalinitenin kahverengi ve beyaz elyaf değerlerine yaklaştığ 1 gözlemlenmiştir [26].

Gürel, Akdemir ve Karadayı (2001) doğal renkli elyaflı pamuk genotiplerinin değerlendirilmesini amaçlamıştır. Ege Bölgesinde Menemen, Ödemiş ve Nazilli'de iki yıl süre ile gerçekleştirilen araştırmada, 4 kahve ve 2 yeşil renkli hattı içeren 6 adet renkli pamuk genotipi, 3 beyaz elyaflı kontrol pamukları ile denemeye alınmış̧ır. Projede pamukların lif uzunlukları, incelikleri ve mukavemetleri kıyaslanmıştır. Proje sonucunda deve tüyü hattı 33,9-30,2 mm lif uzunluğu ve 290-219 kg/da kütlü verimi vermiş̧tir. Kahve renkli hattın ise 26,0-25,9 mm lif uzunluğuna ve 458,0-376,1 kg/da kütlü verimine sahip olduğu belirlenmiştir. Yeşil renkli elyaflı pamuklar ise, diğer pamukların gerisinde kalmıştır [24].

Parmar ve Chakraborty (2001) tarafindan yapılan bir çalışmada, devetüyü ve zeytin yeşili doğal renkli pamuklarla, beyaz pamuk liflerinin fiziksel özellikleri, ağır metal içerikleri tespit edilmiş ve kıyaslanmıştır. Doğal renkli pamuklar ile beyaz pamuk karşılaştırıldığında, renkli pamuğun lif uzunluğu ve mukavemetlerinin daha düşük olduğu görülmüsştür. Bu durumun doğal renkli pamukların ağır metal içeriğinin fazla olmasından ve içerdiği kül miktarının diğerlerine göre yüksek olmasından kaynaklandığı savunulmuştur. Doğal renkli pamukların yanma davranışları incelendiğinde limit oksijen indeksi değerinin beyaz pamuklara göre yüksek olduğu ve dolayısıyla da 
tutuşabilirliklerinin daha düşük olduğu tespit edilmiştir. Ayrıca beyaz pamuğun, diferansiyel taramalı kalorimetre çalışmalarında selüloza ve hemiselüloza ayrışması ve buharlaşarak bozulması yaklaşık $370^{\circ} \mathrm{C}$ civarında gerçekleşirken, bu değerin doğal renkli pamuklar için $390^{\circ} \mathrm{C}$ civarında olduğu gözlemlenmiş̧tir [19].

Price, Cui ve Calamari (2001), Arizona Üniversitesi tarafindan yetiştirilen doğal açık tarçından yeşil renge kadar değiş̧en dört pamuk çeşidinin endüstriyel aletler kullanılarak çırçırlanıp eğirilerek ring ve rotor ipliklerine dönüştürüldüğünü belirtmişlerdir. Pamukları karşılaştırmak için lif ve iplik testleri uyguladıklarını ve ipliklerin dokuma fabrikasına dokunmak üzere gönderildiğini bildirmişlerdir. Mikroner değerinin renk tonunu değiştirdiğine dair bulgular saptamışlardır. Araştırmalar sonucunda en düşük mukavemetli ve en kısa pamuk lifi olan koyu tarçın renkli pamuk liflerinden üretilen ipliğin en dayanıksız ve en düzgünsüz olduğu saptanmıştır. Dört farklı doğal renkli pamuk kıyaslandığında en uzun, kaba ve dayanıklı çeşidin şampanya renkli pamuk olduğu ve en sağlam ve en düzgün ipliklerin doğal yeşil renkli pamuklardan elde edildiği söylenebilir. Çalı̧̧mada dayanım ve iplik düzgünlüğü yönünden doğal açık tarçın ve şampanya renkli pamukların benzerlik gösterdiği belirtilmiştir [27].

Hustvedt ve Crews (2005) tarafindan yapılan çalışmada üç renkte (yeşil, taba ve kahverengi) doğal pigmentli pamuğun ultraviyole koruma (UPF) değerlerinin yanı sıra ışığa maruz kalma ve yıkama işleminin doğal pigmentli pamuğun UV koruyucu özellikleri üzerindeki etkileri araştırılmıştır. Ksenon ışığına maruz kalma ve yıkama sonucunda, doğal pigmentli pamuğun solduğu tespit edilmiş olsa da tüm tonlar için UV koruma faktörünün yeterince yüksek olduğu belirtilmiştir. Sonuç olarak doğal pigmentli pamuklardan elde edilen kumaşların, geleneksel pamuktan (ağartılmış veya ağartılmamış) elde edilen kumaşlara göre önemli ölçüde daha yüksek UV koruma faktörü sergilediği görülmüştür [17].

Gu (2005), NaOH çözeltisi kullanarak doğal olarak yeşil renkli pamuğun nem emiciliğini iyileştirmeye çalışmıştır. Hidrofobik bileşenlerin $\mathrm{NaOH}$ çözeltisi ve damıtılmış 1lık suyla uzaklaştırılmasından sonra, doğal renkli yeşil pamuğun nem geri kazanımının, beyaz pamuğun nem emiciliğine benzer şekilde $\% 8,81$ 'e yükseldiğini saptamıştır [28].

Matusiak ve ark. (2007) tarafından yapılan çalışmada Yunan menşeili kahverengi pamukların elyaf özelliklerinin, farklı eğirme teknolojileri kullanılarak elde edilen ipliklerin özelliklerinin ve bu ipliklerden elde edilen kumaşların yapısal/mekaniksel özellikleri (mukavemet, uzama) ile termofizyolojik özelliklerinin (hava geçirgenliği, hidrofilite, termal konfor) tespiti gerçekleştirilmiştir. Yunan menşeli kahverengi pamuğun, düşük olgunluk, yüksek neps, çöpel ve toz özelliklerine sahip olmasına rağmen, $\mathrm{OE}$ iplik üretiminde kullanılabileceği belirtilmiştir. Ancak doğal renkli pamuktan üretilecek $\mathrm{OE}$ ipliğin kalitesinin ipliğe verilecek olan büküm miktarına bağlı olduğu vurgulanmıştır. Kahverengi pamuktan üretilen düşük mukavemetli ipliğin dokumada çözgü ipliği olarak kullanılmasında herhangi bir sorun olmayacağı, ancak çözgü ipliğindeki düşük mukavemetli kahverengi pamuk liflerinin yıkanan kumaşların çözgü yönündeki dayanımında belirgin düşüşe yol açabileceği belirtilmiştir. Bunun ötesinde renkli pamuk ve renkli pamuk karışımlarından yapılan kumaşların termal özelliklerinin beyaz pamuktan yapılmış olanlara benzediği, ancak kahverengi pamuktan yapılan kumaşların beyaz pamuktan üretilenlere göre daha yumuşak tutuma sahip olduğu ifade edilmiştir [29].

Üte ve ark. (2008) yaptığı çalışmada doğal renkli pamuk lifi ile Angora tavşanı lifini farklı oranlarda karıştırarak iplikler üretmiş ve bu ipliklerden çift yüzlü örme kumaşlar elde etmiştir. Bu kumaşlardan birincisi tene temas edecek yüzeyin \%100 doğal renkli pamuk, diğer yüzeyin angora / doğal renkli pamuk karışımı olacak şekilde üretilmiştir. İkinci kumaş kontrol numunesi olup her iki yüzeyinde de \%100 doğal renkli pamuk kullanılarak üretilmiştir. Üretilen kumaşların ısıl konforları ölçülmüş, farklı yüzlerin iç veya dış katman olarak kullanılmasının ve değişik angora oranının bu özelliklere etkisi incelenmiştir. Bu çalışmada angora / pamuk karışım oranının iplik özellikleri üzerine etkileri de irdelenmiş̧tir. Buna göre Angora elyaf oranı belli bir yüzdeye kadar doğal renkli pamuk elyafının özelliklerinin iyileştirilmesine yardımcı olurken belli bir karışım yüzdesinden sonra elyaf özelliklerini ilk değerlerinden daha kötü bir duruma getirdiğini göstermiştir [30].

Kang ve Epps (2009) yaptıkları çalışmada enzimatik işlemin üç farklı doğal renkli pamukta düşük nem geri kazanımını iyileştirip iyileştiremeyeceğini incelemişlerdir. Enzimatik işlemden sonra renkli pamukların ağırlığında artış saptamışlardır. Bu artışın nedenini belirlemek için nem geri kazanım testi uygulanmış ve üç doğal renkli pamuğun nem geri kazanımının bazik işlem sonrasında arttığı ve enzim işleminden sonra daha da arttığı görülmüştür. İstatistiksel sonuçlar, lipazın kahverengi pamuklar için en az etkili ve yeşil pamuk için en etkili enzim olduğunu göstermiş̧tir. Çoklu enzim muamelesi için, amilaz içeren işlemlerin en çok kahverengi pamuklar için ve lipaz içeren işlemlerin en çok yeşil pamuk için etkili olduğu tespit edilmiştir [13].

Chen ve Cluver (2010) yaptıkları araştırmada, toprak altına gömme ve laboratuvar küf kültürü koşulları altında konvansiyonel beyaz ve boyalı pamuğa kıyasla doğal renkli pamuğun biyodegradasyon ve küf direnci özelliklerini incelemişlerdir. Laboratuvar küf kültürü sonuçları doğal kahverengi ve yeşil renkli pamuklu kumaşların Aspergillius niger'in büyümesine karşı direnç gösterdiğini ortaya koymuştur. Bununla birlikte, toprak altında 28 gün bekletildikten sonra, doğal renkli pamukların, boyanmış veya boyanmamış konvansiyonel beyaz 
pamuklara göre daha iyi fiziksel görünüme sahip olmalarına karşın, doğal renkli pamuk numuneleri belirgin bir mukavemet kaybına uğramış ve numunelerden alınan lifler yapısal hasara uğramıştır. Bu, doğal renkli pamukların biyolojik olarak parçalanabileceğini, ancak boyanmış veya boyanmamış konvansiyonel pamuklara göre daha düşük bir hızda (özellikle yeşil renkli pamukta daha belirgin olmak üzere) meydana geleceğini ortaya koymaktadır. Ayrıca, doğal yeşil pamuğun toprak altına gömme koşulları altında doğal kahverengi renkli pamuktan daha az bozuşmasının nedeni, kahverengi pamukların beyaz türlere daha benzer bir yapıya sahip olmasına karşın, yeşil pamukların ise önemli ölçüde farklı olmasına dayandırılmıştır. Doğal yeşil renkli pamuk, doğal kahverengi renkli pamuktan daha pürüzsüz bir yüzey yapısına ve çok daha yüksek vaks içeriğine sahiptir. Doğal renkli pamukların boyanmış pamuğa göre daha yavaş bir hızda biyobozunur olması ise, pamuğu boyamak için kullanılan boyaların çoğunun azo esaslı direkt ve reaktif boyalar olmasıyla açıklanmıştır. Bu boyaların, aerobik veya anaerobik bakteriler tarafından kolayca indirgenebilen veya yükseltgenebilen bir azo bağı, $-\mathrm{N}=\mathrm{N}$ - içermelerine karşın, doğal renklendiricilerin daha karmaşık olması, doğal renkli pamukların aerobik veya anaerobik bakteriler yoluyla indirgenmeleri ve / veya oksidasyona uğramalarının daha zor olmasının nedeni olarak gösterilmiștir [31].

Değirmenci, Kireçci ve Kaynak (2010) doğal devetüyü rengindeki ve beyaz renkteki pamuktan üretilmiş dokuma ve örgü ipliklerinin özelliklerini incelemiş ve bunları kumaş haline getirmiştir. Yapılan haslık testleri doğal renkli pamuklardan üretilen kumaşların ışık haslığı dışında kalan tüm haslıklarının beyaz pamuktan üretilip boyanmış olan kumaşın haslık değerlerine yakın veya daha iyi olduğunu göstermiștir [5].

Chae, Lee ve Cho (2011) doğal renkli organik pamuğun mekanik özelliklerinin dokunsal duyusal algilar açıdan incelenmesi için bir çalışma yapmıştır. İki tür, kahverengi ve yeşil renkli pamuk lifleri seçilmiş ve bunlar bezayağı ve dimi kumaşlar halinde dokunmuştur. Mekanik özellikler Kawabata Handle (KES-FB) sistemi ile değerlendirilmiștir. Çalıșma sonucunda, renkli pamuktan üretilen kumaşların mekanik özellikleri ve dokunsal duyusal algıları incelenmiştir. Araştırmacılar, dört farklı doğal renkli organik pamuklu kumaşın kesme, yüzey, sıkıştırma özellikleri ve ağırlı̆̆ı arasında önemli farklılıklar olduğu sonucuna varmıştır. Tutum özelliği açısından kahverengi renkli pamuktan üretilen dimi kumaşın bayan yazlık elbisesi için en uygun olduğu sonucuna varılmıştır [32].

Ma ve ark. (2013) yaptığı çalışmada doğal renkli pamukların antibakteriyel özelliklerini araştırmıştır. Geleneksel beyaz pamukla karşılaştırıldığında, kahverengi pamuğun iki bakteri türü olan Staphylococcus aureus ve Klebsiella pneumoniae ile temas ettiğinde sırasıyla $\% 89,1$ ve $\% 96,7$ azalma oranı ile mükemmel antibakteriyel aktivite sergilediği, yeşil pamuğun antibakteriyel etkisinin ise zayıf olduğu bulunmuştur. Renkli pamukların antibakteriyel mekanizmasını araştırmak için, disk difüzyon yöntemi kullanılarak antibakteriyel aktivitelerinin belirlenmesi için renkli liflerden pigmentler ekstrakte edilerek kimyasal yapıları analiz edilmiştir. Sonuçta kahverengi pamuk liflerinden gelen pigmentin iki bakteri türüne karşı önemli bir aktivite gösterdiği, buna karşın yeşil pamuk lifinden gelen pigmentin sergilediği aktivitenin önemsiz olduğu görülmüsştür. Bu durum, renkli pamuk liflerinin antibakteriyel etkinliğinin yapısındaki pigmentin kimyasal yapısı ile yakından ilişkili olduğunu ortaya koymaktadır. Analiz sonuçları kahverengi pamuktaki pigmentin kondanse tanenlere ait olduğunu ve yeşil pamuktan elde edilen pigmentin ise flavonoid olarak tanımlandığını göstermiştir. Yüksek sıcaklık muamelesinin kahverengi pamuktan ekstrakte edilen pigmentin antibakteriyel aktivitesi üzerindeki etkisi de incelenmiştir. Genel olarak yüksek sıcaklık fiksaj işlemlerinin antibakteriyel aktiviteyi azalttı̆̆ı, ancak antibakteriyel aktivitenin hâlâ tatmin edici bir seviyede olduğu görülmüştür. Bu durum kahverengi pamuğun yüksek sıcaklıktaki fiksaj işlemleri sonrası bile kalıcı antibakteriyel performans gösterebildiğini ortaya koymaktadır [33].

Hinchliffe ve ark. (2015) yaptıkları bir karşılaştırmalı çalışmada, beyaz renkli pamuk ve doğal renkli kahverengi pamuk elyafindan iğneleme ve su jeti yöntemi ile üretilmiş dokusuz kumaşların fiziksel ve yanma özelliklerini araştırmışlardır. Kahverengi pamuk elyafindan üretilen kumaşlarda beyaz liflere kıyasla önemli ölçüde daha yüksek alev geciktirme derecesi gözlenmiştir. Element analizleri, kahverengi pamuk liflerinde, fosfor ve magnezyum dâhil olmak üzere bilinen alev geciktirici elementlerden yüksek seviyede bulunduğunu ortaya koymuştur. Kahverengi pamuk elyafindan iğneleme ve su jeti yöntemi ile üretilmiş dokusuz kumaşların yanma sürelerinin, yapılan $45^{\circ}$ 'lik yanma testleri sonucunda, beyaz kumaşa göre, sırasıyla 30 ve 4 kat daha uzun süreye sahip olduğu tespit edilmiştir. Su jeti yöntemi ile üretilmiş dokusuz kumaşların yanma süresinin azalmasının ana nedeninin ise fosfor içeriğinin azalması olduğu ifade edilmiştir [34].

Ma ve ark. (2016) yaptıkları diğer bir çalışmada ise doğal kahverengi renkli pamuk liflerinin antioksidan özelliklerini araştırmışlardır. Doğal kahverengi renkli pamuğun antioksidan özelliklerinin beyaz pamuğa göre anlamlı derecede yüksek olduğu sonucuna varılmıştır. Liflerdeki fenolik pigment bileşimin antioksidan özelliklere katkıda bulunduğu tespit edilmiştir. Bu eşsiz özelliğin, yıkamadan sonra da kalıcı olduğu bildirilmiştir [35].

Gülïmser (2016) yaptığı çalışmada doğal kahverengi renkli pamuklu örme kumaşın, beyaz pamuklu örme kumaşla boyahanedeki proses adımları ve maliyet açısından bir kıyaslamasını yapmışır. Hesaplamaları kumaşların üretimdeki işlem adımlarını göz önüne alarak gerçekleştirmiş̧ir. Doğal renkli pamuk yıkama ve 
yumuşatma adımları açısından değerlendirilmiştir. Beyaz pamuklu kumaş doğal renkli pamuk ile laboratuvarda aynı renkte boyanmış ve ağartma, boyama, yıkama ve yumuşatma adımları açısından kıyaslanmıştır. Hesaplamalar ve kıyaslamalar enerji, su, işgücü, elektrik, kimyasal, yardımcı madde ve boyarmadde maliyetleri dikkate alınarak yapılmıştır. Sonuç olarak doğal renkli pamuklu kumaşın beyaz pamuklu kumaşa kıyasla boyahanedeki işlemlerinin 2,9 kat daha ucuz olduğu ifade edilmiştir [8].

Nam ve ark. (2016), kahverengi pamuğun rengiyle ilişkili olduğu bilinen kondanze tanenlerin varlığını farklı seviyelerde inorganik bileşenler, kristalinite ve tanen içeren iki seçilmiş kahverengi pamuk genotipini (SA-1 ve MCBL) kullanarak 13C NMR analizi ile doğrulamıştır. İnorganik elementlerin ve tanenlerin etkilerini, lifleri çeşitli çözeltilerde yıkamadan önce ve yıkamadan sonra, termogravimetrik analiz (TG) ve mikro ölçekli yanma kalorimetrisi (MCC) parametreleri ile analiz etmişlerdir. Bu araştırmaların sonuçları, daha önceki çalışmalarda önerilen faktörler hakkında fikir sahibi olunmasını sağlamıştır. Buna göre inorganik bileşenler, pamuk lifinin termal özelliklerini etkilemede kristallikten daha baskındır ve kondanze tanenler metal iyonlarını ve iç termal direnci adsorbe etme yetenekleri nedeniyle kahverengi pamuğun daha yavaş yanmasına katkıda bulunmaktadır [36].

Rathinamoorthy ve Parthiban (2019) tarafından yapılan bir çalışmada kahverengi renkli pamuk ipliği rotor eğirme teknolojisi kullanılarak eğrilmiş ve iplik özellikleri analiz edilmiştir. Dokuma tekniği kullanılarak üç farklı kumaş tipi geliştirilmiş ve geliştirilen kumaşların yırtılma mukavemeti, buruşma geri kazanımı, sertlik, hava geçirgenliği, aşınma ve boncuklanma direnci gibi fiziksel özellikleri değerlendirilmiştir. Süblimasyon, yıkama ve 1şığa karşı renk haslığı gibi haslık özellikleri de incelenmiş ve sonuçlar umut verici bulunmuştur [12].

Günaydın ve ark. (2019) yaptığı çalışmada iki beyaz pamuk çeşidi ve üç doğal renkli kahverengi pamuk çeşidinden elde edilen karde ipliklerle bezayağı, dimi ve ribs olarak dokunmuş kumaşlarda pamuk tipinin kumaşın bazı mekanik özelliklerine ve hava geçirgenliğine olan etkileri araştırılmıştır. İplik ve kumaş özellikleri istatistiksel olarak değerlendirilmiştir. Yapılan analizler beyaz ve doğal renkli pamuktan üretilmiş kumaş numunelerinin bazı mekanik ve hava geçirgenliği özellikleri açısından önemli farklılıklara sahip olduğu tespit edilmiştir. Sonuç olarak, beyaz ve doğal renkte organik Türk pamuğu kullanılan kumaşlarda, tatmin edici mekanik özellik ve hava geçirgenliği seviyeleri elde edilmiş, bu da bu numunelerin üst giyim alanı için kullanılabileceğini ortaya koymuştur [37].

\section{Sonuç}

Katma değeri düşük basit-sıradan mallarla Uzakdoğu ile rekabetin zor olduğu günümüz koşullarında tekstil üretiminin odaklanması gereken önemli bir alan yenilikçi niş ürünlere yönelmektir. Söz konusu yenilikçi ürünler uygun pazarlama stratejileri ile de birleştirildiğinde yüksek gelir eldesi konusunda önemli firsatlar sunmaktadır. $\mathrm{Bu}$ açıdan beyaz pamuğa alternatif bir ürün olarak sunulan doğal renkli pamuğun bunu yetiştiren ve bitmiş ürüne kadar dönüştürerek pazarlayan ülkelere önemli ekonomik kazanımlar sunduğu söylenebilir. Bugün renkli pamuktan üretilmiş bir ipliğin benzeri kalitedeki bir beyaz pamuk ipliğine göre 8-10 kat daha yüksek fiyata satıldığı dikkate alındığında durum daha net bir şekilde anlaşılabilmektedir.

Renkli pamuk her ne kadar daha düşük lif üretim verimi, daha kötü fiziksel-teknolojik özellikler (incelik, uzunluk, mukavemet vb.), ışık ile daha yüksek renk solması, sınırlı renklere ve kısıtlı bir pazara sahip olma gibi dezavantajlar içerse de; çevre kirliliğine ve insan sağlığına olumsuz etkisinin daha az olması, bu liflerden üretilen kumaşın işlem maliyetinin, yanıcılığının ve yıkama sonrası renk solmasının daha az olması ve daha yüksek UV koruma özelliğine sahip olması gibi önemli avantajlar sunduğu göz ardı edilmemelidir. Öte yandan çevre dostu üretimin büyük önem kazandığı günümüz koşullarında atık yükü oluşturmayan yeni proseslerin ve üretim yöntemlerinin geliştirilmesi artık bir zorunluluk haline gelmeye başlamıştır. Terbiye prosesleri arasında en fazla atık yükü oluşturan boyama işlemlerini ortadan kaldırmanın ve böylece önemli çevresel avantajlar elde etmenin bir yolu doğal lifin renkli olarak yetiştirilmesidir. Renkli pamuk üretimi her ne kadar uzun yıllar önce başarılmış bir konu olsa da literatür incelendiğinde renkli pamukların başta mekanik özellikler açısından beyaz pamuğa göre geride kalıyor olması bu liflerin yaygın kullanımı üzerinde önemli bir engel teşkil ettiği anlaşılmaktadır. Bu nedenle, bir yandan renkli pamuk yetiştiriciliği konusunda bu liflerin tekstil alanında kullanılabilirliğini engelleyen sorunlara çözüm üretecek araştırmaların yapılması gerekirken öte yandan mevcut durumu ile renkli pamuğun ne gibi alanlarda değerlendirilebileceğini ortaya koyan ürüne yönelik çalışmalar yapılması gerektiği düşünülmektedir.

\section{Kaynaklar}

[1]. Kalebek NA. Investigation of mechanical properties of yarns and fabrics produced naturally colored cotton fibers, M.Sc. University of Gaziantep, Textile Engineering Department, Gaziantep, 2003 
[2]. Hua S, Wang S, Yuan X, Shao M, Zhao X, Zhu S, Jiang L. Characterization of Pigmentation and Cellulose Synthesis in Colored Cotton Fibers, Crop Sci. Soc. of America, 2007; 47(4): 1540-1546

[3]. T.C. Gümrük ve Ticaret Bakanlığı Kooperatifçilik Genel Müdürlüğü, Pamuk Raporu, 2019

[4]. https://www.textilegence.com/dogal-renkli-pamuk/, Erişim Tarihi: 14.02.2020

[5]. Değirmenci Z, Kireçci A, Kaynak H. Doğal renkli pamuktan elde edilen dokuma ve örme kumaşların haslık özelliklerinin araştırılması. Tekstil Teknolojileri Elektronik Dergisi, 2010; 4(2): 30-42.

[6]. Dutt Y, Wang XD, Zhu YG, Li YY. Breeding for high yield and fibre quality in coloured cotton. Plant Breeding, 2004; 123(2): 145-151

[7]. Dickerson DK, Lane EF, Rodriguez DF. Naturally colored cotton: Resistance to changes in color and durability when refurbished with selected laundry aids, Fresno: California Agricultural Technology Institute, California State University, 1999; 1-42

[8]. Gülümser, T. Comparison between naturally colored cotton fabric and white cotton fabric in manner of processes in the dyehouse. Tekstil ve Konfeksiyon, 2016; 26(3): 287-294

[9]. Vreeland JM. The Revival of Colored Cotton. Scientific American. New York. 1999; 280(4): 112-119.

[10]. Dodmani MT. Production and value addition in naturally coloured cotton under contract farming -an economic analysis, University of Agricultural Sciences, Dhanuad, 2006

[11]. Gong W, Du X, Jia Y, Pan Z. Color Cotton and Its Utilization in China, Cotton Fiber: Physics, Chemistry and Biology, Springer, 2018; 117-132

[12]. Rathinamoorthy R, Parthiban M. Colored cotton: Novel eco-friendly textile material for the future. In Martinez LMT et al (Eds.), Handbook of ecomaterials, Cham, Switzerland: Springer International Publishing AG. 2019; 1499-1519

[13]. Kang SY, Epps HH. Effect of scouring and enzyme treatment on moisture regain percentage of naturally colored cottons, The Journal of The Textile Institute, 2009; 100(7), 598-606

[14]. Yatsu LY, Espelie KE, Kolattukudy PE. Ultrastructural and chemical evidence that the cell wall of green cotton fiber is suberized. Plant Physiology, 1983; 73(2): 521-524

[15]. Schmutz A, Jenny T, Amrhein N, Ryser U. Caffeic Acid and Glycerol are Constituents of the Suberin Layers in Green Cotton Fibres, Planta, 1993; 189(3): 453-460.

[16]. Schmutz A, Jenny T, Ryser U. A caffeoyl-fatty acid-glycerol ester from wax associated with green cotton fibre suberin. Phytochemistry, 1994; 36(6): 1343-1346.

[17]. Hustvedt G, Crews PC. The ultraviolet protection factor of naturally-pigmented cotton. The Journal of Cotton Science, 2005; 9(1): 47-55.

[18]. Halloin JM. Localization and changes in catechin and tannins during development and ripening of cottonseed. New Phytologist 1982; 90: 641-657.

[19]. Parmar MS, \& Chakraborty M. Thermal and burning behavior of naturally colored cotton. Textile Research Journal, 2001; 71(12): 1099-1102

[20]. http://www.ideassonline.org/public/pdf/ColoredCotton-ENG.pdf

[21]. Williams B. FoxFibre naturally colored cotton, green and brown (coyote) resistance to changes in color. Ph.D diss. Texas Tech. Univ., Lubbock, TX. 1994

[22]. Garcia S, Naas IDA. Textile industry can be less pollutant: introducing naturally colored cotton, International Journal of Production Management and Engineering (Int. J. Prod. Manage. Eng.), 2014; 2(2): 85-91

[23]. Botao H. Views of the Colors of Natural Cotton-colored and Several Question in Production, Cotton Textile Technology, 2002; 05

[24]. Gürel A, Akdemir H, Karadayı HB. (2001). Doğal renkli elyaflı pamukların Ege bölgesi koşullarında üretilme olanakları, Anadolu, J. of AARI, 2001; 11(1): 56-70

[25]. VanZandt MJ, Horridge P, Dever JK. Flame resistance and physical characteristics of upholstery-weight naturally colored cotton. Cloth Text. Res. J. 1997; 15(4):246-251

[26]. Richards AF, Rowe, T, Stankovic Elesini U. Structure of naturally coloured cottons. Journal of the Textile Institute, 1999; 90(4): 493-499.

[27]. Price JB, Cui X, Calamari TA. Assessing the Quality of Four Naturally Colored Cottons. Textile Res. J. 2001; 71(11): 993-999.

[28]. Gu H. Research on the improvement of the moisture absorbency of naturally self-coloured cotton. The Journal of The Textile Institute, 2005; 96, 247-250.

[29]. Matusiak M, Kechagia U, Tsaliki E, Frydrych IK. Properties of the naturally colored cotton and its application in the ecological textiles. In 4th World Cotton Research Conference, Lubbock, USA, 2007

[30]. Üte TB, Oğlakçıŏlu N, Çelik P., Marmaralı A., Kadoğlu H. Doğal Renkli Pamuk ve Angora Tavşanı Lifi Karışımından Üretilen İpliklerin Özellikleri ve Örgü Kumaşların Isıl Konforuna Etkileri Üzerine Bir Araştırma, Tekstil ve Konfeksiyon, 2008; 18(3): 191-197.

[31]. Chen H, Cluver B. Biodegradation and mildew resistance of naturally colored cottons. Textile Research Journal, 2010; 80(20): 2188-2194

[32]. Chae Y, Lee M, Cho G. Mechanical properties and tactile sensation of naturally colored organic cotton fabrics. Fibers and Polymers, 2011; 12(8): 1042-1047.

[33]. [33] Ma M, Li R, Du Y, Tang Z, Zhou W. Analysis of antibacterial properties of naturally colored cottons. Textile Research Journal, 2013; 83(5): 462-470 
[34]. Hinchliffe DJ, Condon B, Delhom CD, Chang S, Montalvo J, Madison C, Reynolds M, VonHoven T, Santiago Cintro'n M. Physical and combustion properties of non-woven fabrics produced from conventional and naturally colored cottons. Textile Research Journal, 2015; 85(16):1666-1680

[35]. Ma M, Luo S, Hu Z, Tang Z, Zhou W. Antioxidant properties of naturally brown-colored cotton fibers. Textile Research Journal, 2016; 86(3): 256-263.

[36]. Nam S, Kim HJ, Condon BD, Hinchliffe DJ, Chang S, McCarty JC. Madison, C. A. High resistance to thermal decomposition in brown cotton is linked to tannins and sodium content. Cellulose, 2016; 23(2): 1137-1152.

[37]. Gunaydin, GK, Palamutcu S, Soydan AS, Yavas A, Avinc O, Demirtas M. Evaluation of fiber, yarn, and woven fabric properties of naturally colored and white Turkish organic cotton. The Journal of The Textile Institute, 2019; 111(10): 1436-1453 